American Journal of Biochemistry and Biotechnology 6 (1): 47-53, 2010

ISSN 1553-3468

(C) 2010 Science Publications

\title{
Potentials and challenges of Participation in Agricultural Biotechnology R and D: A Case for National Agricultural Research Capacity Building
}

\author{
${ }^{1}$ A.E. Adekoya and ${ }^{2}$ T.A. Adisa \\ ${ }^{1}$ Department of Agricultural Extension and Rural Development, \\ Faculty of Agriculture and Forestry, University of Ibadan, Ibadan, Oyo State, Nigeria \\ ${ }^{2}$ Federal College of Animal Health and Production Technology, \\ National Veterinary Research Institute, PMB 01, Vom, Plateau State, Nigeria
}

\begin{abstract}
Problem statement: Scientists in National Agricultural Research Institutes and University faculties of agriculture and veterinary medicine were surveyed to explore their participation in agricultural biotechnology research in Nigeria. Multistage sampling was used. Approach: Two Federal universities and two state universities were randomly selected from a list of Federal and State universities. In addition to these, one university each was selected from the four universities of Technology and three Federal universities of Agriculture. Results: Forty three scientists were purposively selected based on participation in agricultural biotechnology research. Nine research institutes were purposively selected based on their mandates. A total of 105 scientists were selected from the research institutes, based on their participation in agricultural biotechnology research. The total number of respondents from the selected amounted to 148. A structured questionnaire was used. Majority of the respondents fell within the medium participation category $(63.5 \%)$. There is a significant relationship between availability of training/self development opportunities $(\mathrm{r}=0.278$, $\mathrm{p}<0.05)$ and career advancement opportunities $(\mathrm{r}=0.348, \mathrm{p}<0.05)$ and participation in agricultural biotechnology research. Inadequacy of electricity supply was significantly related to participation. Regression analysis show that human resources capacities available to scientists had positive relationship with participation in agricultural biotechnology research and development but only career advancement opportunities $(r=0.003, p<0.05)$ and royalties on findings $(r=0.151, p<0.05)$ were significant. Conclusion/Recommendations: There is need for strengthening both human resources and infrastructural capacity to increase participation in agricultural biotechnology research in Nigeria.
\end{abstract}

Key words: Participation, scientists, biotechnology, research

\section{INTRODUCTION}

Much effort has gone into tackling the challenge of intractable food shortages in Nigeria. On the one hand population growth has been spiraling over the decades, with the latest rate put at $2.6 \%$, while on the other hand food import bills have been on the increase. Despite its enormous potentials in agricultural production, Nigeria has had to at one time or the other resort to aid dependence to meet its local food requirement. In the year 2003 for example, Nigeria received 11,000.6 metric tones of soy meal as food aid from the US Food for Progress Programme (Olaniyan et al., 2007). The consensus among many development interests in the country is that there is an urgent need to develop the ability of the agricultural system to produce at such a level that can ensure food security. For many in research circles, agricultural biotechnology presents a very viable promise for this.

Agricultural biotechnology is increasingly seen as a valuable tool for addressing production and nutritional constraints in developing countries, particularly in commodities important to poor producers and consumers. Modern biotechnology tools have the potential to significantly raise agricultural productivity in a more environmentally friendly-manner, supply cheaper and more nutritious food, and contribute to poverty alleviation (The World Bank, 2005).

Nigeria has made considerable efforts at jumpstarting the process of developing a viable agricultural biotechnology research and development system. The aspiration is that, such a research system

Corresponding Author: A.E. Adekoya, Department of Agricultural Extension and Rural Development,

Faculty of Agriculture and Forestry, University of Ibadan, Ibadan, Oyo State, Nigeria 
will be capable of adapting already available technology to the local environment for use by farmers and also have the wherewithal to develop new, homegrown biotechnologies for agricultural production and food processing. This is in consonance with the observation of (FAO, 2004), that countries that were able to make the most of the opportunities presented by the Green Revolution of the 1970's were those that had or quickly developed strong national capacity in agricultural research. Scientists in those countries were able to make the necessary local adaptations to ensure that improved varieties and other inputs suited the needs of local farmers and consumers.

In addition to the establishment of specialized agencies to promote and regulate the development of agricultural biotechnologies in the country, there have been reports of quite some activity at the research level. Some biotechnology projects in national agricultural research laboratories across the country include: development of protocols for some selected crops, micro propagation of some crops and herbs, production of improved planting materials of pineapple, banana, plantain, sugarcane and pathogen elimination in some crops (Sonnino et al., 2009). These projects are either with the use of tissue culture or molecular biology applications. There has not been any record of research in genetic modification of any crop in national agricultural research laboratories in the country. Only international research organizations like the International Institute of Tropical Agriculture (IITA), which is an institute of the Consultative Group on International Agricultural Research (CGIAR) is carrying out research involving genetic engineering in the country.

It is important to highlight the fact that the aforementioned efforts notwithstanding, farmers, especially smallholders, who form the bulk of the production system, are yet to be helped out of their rudimentary practices. These smallholders still face the same challenges of pests, diseases and the use of low yielding varieties/breeds of crops and livestock. The research activities at the various research organizations lack the capacity to produce results that can deal with these perennial problems. Scientist in the national agricultural research system are forced to work within an environment described as lacking in capacity. This inadequacy in the research environment incapacitates the scientists and limits their effectiveness.

Statement of problem: Research and development in agricultural biotechnology currently places a challenge on the existing capacity for agricultural research in Nigeria. In a regional study of national agricultural research capacities Nigeria was rated the best in terms of manpower in the area of agricultural biotechnology research (Alhassan, 2003). The same study however revealed that these scientists operate within an environment that compromises their ability to satisfy the nation's quest for biotechnology for sustainable agricultural development. The current situation shows a lot of activity, but in the rudimentary applications of the technology. Some biotechnology projects in national agricultural research laboratories across the country to include, development of protocols for some selected crops, micropropagation of some crops and herbs, production of improved planting materials of pineapple, banana, plantain, sugarcane, and pathogen elimination in some crops (Sonnino et al., 2009). These projects are either with the use of tissue culture or molecular biology applications. There has not been any record of research in genetic modification in the national agricultural research institutes in the country. Only scientists in the CGIAR institutes like the International Institute for Tropical Agriculture (IITA) are making efforts in this regard.

In an assessment of the potential for sustainable development and deployment of biotechnology for agricultural research in Nigeria, a survey conducted in 2005 revealed that $53.2 \%$ of Nigerian scientists participating in biotechnology research possessed higher degrees. It was equally found out that $46.6 \%$ of these specialized in conventional biotechnology, but just like the other studies, it implicated a dearth in facilities as a limiting factor to participation, with only $27.9 \%$ being motivated by available facilities (Irefin et al., 2005). It is clear that despite having comparably high capability in terms of manpower in the West African sub-region, there is still a deficit in outputs from research. Farmers in Nigeria still contend with farm problems that agricultural biotechnology is supposed to address.

The thrust of this work is to carry out a researchlevel assessment of scientists participating in agricultural biotechnology research in Nigeria vis-à-vis the factors that affect their participation and the potentials existing for effective research and transfer of research outputs. The existence of this gap is confirmed by the very few evaluations that have been carried out to assess existing capacity for the conduct of research and development activities (Horton et al., 2003). It is the confluence between the critical mass of scientists and existence of these capacities for agricultural biotechnology research and transfer that would determine the degree to which farmers would enjoy the benefits that agricultural biotechnology has to offer.

The general objective of this study was to identify the participation of scientists in agricultural 
Am. J. Biochem. \& Biotech., 6 (1): 47-53, 2010

biotechnology research and development activities in Nigeria. The following specific objectives were formulated to guide the study:

- The identification personal characteristics of scientists participating in agricultural biotechnology research

- The identification of their agricultural biotechnology research and development activities The determination of their level of participation

- Identification of the constraints they face

\section{MATERIALS AND METHODS}

The population of the study is scientists in national agricultural research institutes, faculties of agriculture and faculties of veterinary medicine in Nigerian universities who are participating in the use of agricultural biotechnology applications for research.

Multistage sampling was used to draw samples from both universities and national agricultural research institutes.

For universities, two Federal universities and two state universities were randomly selected from a list of Federal and State universities respectively. In addition to these four, one university each was selected from the four universities of Technology and three Federal universities of Agriculture, bringing the total of selected universities to 6 . Forty three scientists were purposively selected from the faculties of agriculture and veterinary medicine, based on participation in agricultural biotechnology research.

Nine research institutes were purposively selected based on their mandates. A total of 105 scientists were purposively selected from the research institutes, based on their participation in agricultural biotechnology research. The total number of respondents from the selected both universities and research institutes amounted to 148 scientists.

A structured questionnaire containing both open and closed ended questions was used to obtain primary information on the activities of scientists in agricultural biotechnology research and development. The questionnaire was subjected to face validity by scientists from various experts in biosciences in the National Veterinary Research Institute, Vom and the Universityof Ibadan, Nigeria.

Participation was determined by providing a list of agricultural biotechnology laboratory/field applications, publication/documentation of biotechnology information, extension and training activities by scientists and participation in development activities in the area of agricultural biotechnology. Respondents indicated the frequency of participation in these activities, i.e., Always $=2$, Sometimes $=1$ and never $=0$. Respondents rated constraints as either Very serious $=3$, Serious $=2$, Not serious $=1$ or Not a constraint $=0$. In addition to these, respondents supplied information relating to their sex, age, years of experience and qualification.

\section{RESULTS}

Table 1 shows the personal characteristics of scientists and the descriptive statistics. There were more male scientists $(81.7 \%)$ than female and more of the females are married $(14.9 \%)$ compared to unmarried $(3.4 \%)$. The modal age range for scientists is $36-45$ years $(53.3 \%)$. With respect to professional profile, $48.6 \%$ had qualification up to the M.Sc level while $23.6 \%$ had Ph.D., $67.5 \%$ are at the senior cadre About 58.1\% have work experience of over 10 years as researchers. Their major activity is conducting of research $(60.8 \%)$.

Table 2 was provided to find out the activities of respondents in agricultural biotechnology research and development activities. Means of participation in each activity were computed and results on Table 2 show that the highest mean was for attendance of seminars on agricultural biotechnology $($ mean $=2)$. This is followed by attendance of conferences and workshops and multiplication of planting materials $($ means $=1.8)$.

\begin{tabular}{|c|c|c|c|}
\hline Variable & Description & Frequency & $(\%)$ \\
\hline \multirow[t]{2}{*}{ Sex } & Male & 121 & 81.7 \\
\hline & Female & 27 & 18.2 \\
\hline \multirow[t]{4}{*}{ Marital Status } & Male (Married) & 109 & 73.6 \\
\hline & Male (Single) & 12 & 8.1 \\
\hline & Female (Married) & 22 & 14.9 \\
\hline & Female (Single) & 5 & 3.4 \\
\hline \multirow[t]{5}{*}{ Age } & $<25$ & 1 & 0.7 \\
\hline & $25-35$ & 33 & 22.3 \\
\hline & $36-45$ & 79 & 53.3 \\
\hline & $46-55$ & 29 & 19.6 \\
\hline & $56-65$ & 6 & 4.1 \\
\hline \multirow[t]{4}{*}{ Qualification } & B.Sc. & 37 & 25.0 \\
\hline & M.Sc. & 72 & 48.6 \\
\hline & M.Phil & 4 & 2.7 \\
\hline & Ph.D. & 35 & 23.6 \\
\hline \multirow[t]{5}{*}{ Experience (years) } & $1-10$ & 62 & 41.9 \\
\hline & $11-20$ & 70 & 47.3 \\
\hline & $21-30$ & 13 & 8.8 \\
\hline & $31-40$ & 2 & 1.4 \\
\hline & $>40$ & 1 & 0.7 \\
\hline \multirow[t]{3}{*}{ Cadre } & Management position & 14 & 9.5 \\
\hline & Senior position & 100 & 67.5 \\
\hline & Intermediate position & 34 & 23.0 \\
\hline \multirow[t]{5}{*}{ Major official activities } & Teaching & 42 & 28.4 \\
\hline & Research & 90 & 60.8 \\
\hline & Extension & 7 & 4.7 \\
\hline & Administration & 5 & 3.8 \\
\hline & Production & 4 & 2.7 \\
\hline
\end{tabular}


Am. J. Biochem. \& Biotech., 6 (1): 47-53, 2010

Table 2: Activities of scientists in agricultural biotechnology R and D

$\mathrm{R}$ and $\mathrm{D}$ activities $\quad$ Mean $\mathrm{SD}$

Type of Laboratory/field application of biotechnology

Fermentation

$\begin{array}{lll}\text { Artificial insemination } & 1.30 & 0.61\end{array}$

Development of biofertilizers (pulses and cereals) $\quad 1.42 \quad 0.69$

$\begin{array}{lll}\text { Tissue culture } & 1.60 & 0.75\end{array}$

Application of In-vitro techniques for breeding $\quad \begin{array}{lll}1.41 & 0.67\end{array}$

$\begin{array}{lll}\text { Ethnoveterinary vaccines } & 1.26 & 0.57\end{array}$

Application of DNA maker techniques $\quad 1.41 \quad 0.65$

$\begin{array}{lll}\text { Multiplication of plant materials } & 1.80 & 0.82\end{array}$

Field trials of biotechnology products $\quad 1.61 \quad 0.71$

$\begin{array}{lll}\text { Genetic modification } & 1.40 & 0.65\end{array}$

Publication/documentation of biotechnology information

$\begin{array}{lll}\text { Journal paper article on agro biotechnology } & 1.90 & 0.76\end{array}$

$\begin{array}{lll}\text { Newsletter publication } & 1.70 & 0.75\end{array}$

$\begin{array}{lll}\text { Extension bulletin on agro biotechnology } & 1.60 & 0.69\end{array}$

Advocacy/opinion article in Newspaper/magazine $\quad \begin{array}{lll}1.60 & 0.71\end{array}$

Extension activities

Participation in exhibition of biotechnology products $\quad \begin{array}{lll}1.60 & 0.77\end{array}$

Radio/Television programmer on agro biotechnology $\quad \begin{array}{lll}1.60 & 0.70\end{array}$

$\begin{array}{lll}\text { Field demonstrations on agro biotechnology } & 1.50 & 0.69\end{array}$

Training

Conferences/Workshops on biotechnology $\quad 1.80 \quad 0.74$

$\begin{array}{lll}\text { Seminars } & 2.00 & 0.68\end{array}$

Special courses in biotechnology $\quad 1.50 \quad 0.65$

Development activities

Securing of patent rights

Grant aided project in biotechnology

Input in national planning on agro biotechnology $\quad 1.30 \quad 0.56$

Source: Field survey. NB: Frequency of participation (Always $=2$,

Sometimes $=1$, Never $=0$ )

Table 3: Levels of participation in agricultural biotechnology research

\begin{tabular}{llcc}
\hline $\begin{array}{l}\text { Levels of } \\
\text { participation }\end{array}$ & $\begin{array}{l}\text { Participation } \\
\text { categories }\end{array}$ & Frequencies & Percentages \\
\hline Low & $9-26$ & 26 & 17.6 \\
Medium & $27-45$ & 94 & 63.5 \\
High & $>45$ & 28 & 18.9 \\
Total & & 148 & 100.0 \\
\hline Source Field survey & &
\end{tabular}

On the aggregate participation, the maximum participation score was found to be 36 while the minimum participation score was 9 , with a standard deviation of 9.63 .

Respondents were categorized into high, medium and low participants in agricultural biotechnology research and development as shown in Table 3. Majority $(63.5 \%)$ fell within the medium participation category, while $17.6 \%$ and $18.9 \%$ fell within the low and high participation categories respectively.

Relationship between variables: Results from spearman rho correlation analysis on Table 4 reveal that there is a significant relationship between availability of training/self development opportunities $(r=0.278$, $\mathrm{p}<0.05)$, career advancement opportunities $(\mathrm{r}=0.348$, $\mathrm{p}<0.05)$, availability of support staff $(\mathrm{r}=0.354, \mathrm{p}<0.05)$, availability of complementary experts $(\mathrm{r}=0.230$, $\mathrm{p}<0.05)$, financial and other incentives $(\mathrm{r}=0.333$, $\mathrm{p}<0.05)$, royalties $(\mathrm{r}=0.504, \mathrm{p}<0.05)$ and supervision from senior scientists $(\mathrm{r}=0.367, \mathrm{p}<0.05)$ and participation in agricultural biotechnology research. These indices collectively measure the human resource capacity for agricultural biotechnology research.

The adequacy of infrastructure for agricultural biotechnology research was measured on a 3 point continuum. Each item was scored as follows: 'Very adequate' $=3$, 'adequate' $=2$ and not adequate $=1$. Scientists rated seven elements (electricity, water, transport, telephone, computers and the internet).

Table 4: Correlation analysis of human resources development opportunities and participation (Spearman rho)

\begin{tabular}{lllllll}
\hline & $\begin{array}{l}\text { Training/self } \\
\text { Variables }\end{array}$ & $\begin{array}{l}\text { Career } \\
\text { development }\end{array}$ & $\begin{array}{l}\text { Complementary } \\
\text { Experts }\end{array}$ & $\begin{array}{l}\text { Support } \\
\text { staff }\end{array}$ & $\begin{array}{l}\text { Financial/other } \\
\text { incentives }\end{array}$ & Royalties \\
\hline Participation & $0.278^{* *}$ & $0.348^{* *}$ & $0.230^{* *}$ & $0.354^{* *}$ & $0.333^{* *}$ & $0.504^{* *}$ \\
& $0.001^{*}$ & $0.000^{*}$ & $0.005^{*}$ & $0.000^{*}$ & $0.000^{*}$ & 0.367 \\
\hline
\end{tabular}

**: Correlation coefficient; *: Significant level

Table 5: Availability of basic infrastructure and participation (PPMC)

\begin{tabular}{llllllll}
\hline Variables & Electricity & Water & Transport & Telephone & Computers & Internet & Participation \\
\hline Correlation coefficients & $0.259^{* *}$ & 0.161 & 0.271 & 0.072 & 0.082 & 0.016 & 1.00 \\
& $0.003^{*}$ & 0.111 & 0.082 & 0.576 & 0.445 & 0.891 & \\
\hline *. Significis
\end{tabular}

*: Significant

Table 6: Human resources development opportunities

\begin{tabular}{lllll}
\hline Variable & SE & Coefficient $(\beta)$ & T & P \\
\hline Constant & 2.421 & & 8.501 & 0.000 \\
Training and self development opportunities & 1.062 & 0.063 & 0.598 & 0.551 \\
Career advancement & 1.006 & 0.200 & 2.118 & 0.036 \\
Availability of field and laboratory support staff & 1.087 & 0.005 & 0.048 & 0.961 \\
Financial and other incentives & 1.194 & 0.003 & 0.031 & 0.975 \\
Royalties on research findings & 0.901 & 0.435 & 4.749 & 0.000 \\
Availability of guidance and research mentoring & 0.827 & 0.151 & 1.019 & 0.071 \\
\hline
\end{tabular}


Am. J. Biochem. \& Biotech., 6 (1): 47-53, 2010

Table 7: Some basic infrastructure for research

\begin{tabular}{lllll}
\hline Variables & SE & Coefficient $(\beta)$ & \multicolumn{1}{l}{ T } & P \\
\hline Constant & 1.076 & & 30.969 & 0.000 \\
Electricity & 0.123 & 0.351 & 3.618 & 0.000 \\
Water & 0.137 & 0.006 & 0.055 & 0.965 \\
Transport & 0.161 & 0.322 & 3.540 & 0.001 \\
Computers & 0.118 & 0.055 & 0.521 & 0.603
\end{tabular}

Availability of facilities does not significantly affect participation in agricultural biotechnology research. These facilities include water $(\mathrm{r}=161, \mathrm{p}>0.05)$, transport $(\mathrm{r}=0.271, \mathrm{p}>0.05)$, telephone $(\mathrm{r}=0.072$, $\mathrm{p}>0.05)$, computers $(\mathrm{r}=0.82, \mathrm{p}>0.05)$ and internet $(\mathrm{r}=0.016 \mathrm{p}>0.05)$. Only the adequacy of electricity supply was found to be significantly related to participation as shown in Table 5.

Regression analysis: Table 6 shows regression analysis of some human resources capacities available to scientists in universities and research institutes in the country. Results show that all the variables had positive relationship with participation in agricultural biotechnology research and development. Only career advancement opportunities $(\mathrm{r}=0.003, \mathrm{p}<0.05)$ and royalties on findings $(\mathrm{r}=0.151, \mathrm{p}<0.05)$ were significant. Human resources capacities were found to predict participation by $36 \%$.

Table 7 show the result of regression analysis of some basic infrastructure required for agricultural biotechnology research. The entire infrastructure related positively to participation, but only electricity and official means of transport for research were significantly related to participation. Basic infrastructure was found to predict participation by $21 \%$.

\section{DISCUSSION}

The study found out that there were more male scientists than female. It is important to note that women are not privy to the information networks and flows that men obtain through their gender specific networks. These networks affect the type and quality of knowledge and knowledge transmission. Gender factors can affect research and extension on many biotechnologies, especially the traditional ones used for processing, which in the African society is traditionally considered a woman's activity.

Age is an important determinant of experience of scientists and by extension their research output. The demands of agricultural biotechnology require the vigor and energy obtainable largely from a virile age bracket and some level of experience in handling the intricacies of research procedure. The low proportion of older researchers in Nigeria has however been attributed to a situation of research staff instability occasioned by frequent exit of older staff over and above normal attrition rates. Most of the scientists that exit the system are older and more experienced.

Qualification scientists is crucial because biotechnology research and development has high scientific content and requires availability of qualified manpower that can handle very sophisticated equipment and processes. The implication of this is the need for high human resource capacity building, most especially investment in human resource development in agricultural biotechnology. It is an intensive research area which needs high human resource capacity to achieve substantial benefits (Ozor, 2008).

Results above show that majority of respondents fall within the medium participation category. Some of the factors responsible for this include poor funding, unavailability of equipment and materials, lack of sufficient training opportunities, inappropriate government policies, high cost of maintaining equipment, and poor fringe benefits to researchers among others. The acceleration of growth in agricultural biotechnology research and development must target specific areas of research capacity building. Such efforts must target development of research activities in areas of advanced biotechnology applications. Results show that much of the activities in the area of tissue culture experiments. Although tissue culture procedures are considered the rudimentary application of agricultural biotechnology, the results show that equipments are not sufficiently available to scientists.

Some critical areas requiring attention in promoting agricultural biotechnology research and development are communication infrastructure, laboratory infrastructure, transport, and electricity supply. Poor state of research infrastructure, especially the paucity or non-availability of modern biotechnology research equipment as the most important constraint to the development of agricultural biotechnology. It is only possible for scientists to participate effectively when laboratory equipment are available and accessible in adequate quantities. The problem of inadequate laboratory equipment is a result of poor funding of institutions in less developed countries like Nigeria. Institutes are expected to stock laboratories and carry on the business of research on a very low budget. Efforts to increase capacity for research through adequately equipped laboratories must start with increased funding to research organizations and universities. 
Although internet access is spreading, the cost is still relatively high. Providing uninterrupted internet access to scientists in universities and research institutes in Nigeria will enhance their ability to access relevant information in a timely and convenient manner in addition to creating avenue for better networking (Alabi et al., 2007). The increasing tendency for scientists to own private Personal Computers (PC's) is making access easier since such PC's serve multiple purposes including research. The development of a strong and reliable communications infrastructure will enhance access to developments in specific areas of agricultural biotechnology and stimulate innovation among scientists. The central activity on which scientific enterprise revolves and is sustained is communication. Access to human resource development opportunities by scientist is crucial in determining their overall output. Such opportunities include training, career advancement opportunities, competitive remunerations and adequate patency protection for research findings, thereby ensuring that they benefit from royalties. Considering the tedium involved in a life-science like agricultural biotechnology research, these motivational elements will impact directly on the stability of scientists and their efficiency in terms of quantity and quality of research output. The present unfriendly work environment as setting the stage for a dearth in skilled personnel to man laboratories for agricultural biotechnology research (Alabi et al., 2007).

\section{CONCLUSION}

The study reveals that majority of the scientist fall within the medium participation level. This agrees with the views of Mathews-Njoku and Adesope (2008) judging Nigeria's activity as not being impressive and stating that Nigeria is not taking the lead in agricultural biotechnology research and development activities in Africa. It is important to note however, as is shown in the findings that with $48.6 \%$ of scientists having M.Sc. and $23.6 \%$ with Ph.D. has the requisite caliber of manpower for an effective agricultural biotechnology $\mathrm{R}$ and D system.

Means of areas of participation in agricultural biotechnology research and development reveal that publication of information in journals and participation in seminars are the higher means. These are activities that enhance exchange of research notes and provide motivation in terms of new problem areas and newer approaches to research.

Percentages by which the independent variables explain participation appear to be low, with $36 \%$ human resources capacity and $21 \%$ infrastructure explaining scientist participation in the use of agricultural biotechnology applications for research. It is important to note however, that most of the activities of scientists in agricultural biotechnology do not cover advanced applications of the technology. Nigerian research organizations do not have capability for advanced forms of agricultural biotechnology research. This is confirmed by Ozor (2008). Who pointed out that the Yitzhak Rabin laboratory for micro-propagation and biotechnology is the only one fully equipped for tissue culture work and probably ranks as the best in that area of research in the country. Other examples of the research activities in agricultural biotechnology research are in the areas of traditional applications like laboratory fermentation, multiplication of planting materials using tissue culture, cleaning of virus infected planting materials and artificial insemination. Some modern applications in the country include marker assisted selection, embryo rescue for yam and DNA finger printing (Alabi et al., 2007).

The result further shows that electricity is a significant predictor of participation in agricultural biotechnology research activities by scientists $(r=3.618$, $\mathrm{p}<0.05$ ). The inadequacy of electricity supply has been fingered as a key constraint to the activity of scientists. The same applies to availability of transport facilities for scientists research activities $(r=3.540, p<0.05)$. It is the opinion of Adeoti and Sinh (2009) Poor R and D infrastructure has limited the intensity and scope of $\mathrm{R}$ and $\mathrm{D}$ in many developing countries.

Implications: Agricultural biotechnology has opened up a window of opportunity for developing nations to deal with their challenges of low income, food insecurity and underdevelopment. These countries have a lot of arable land area that can be utilized to develop vibrant agricultural systems. In the case of Nigeria, the inadequacy of research capacity as a result of its low level of infrastructure has made it difficult to either develop or import and adapt these technologies for local use.

The development of basic infrastructure, like an adequate public water system and a stable power supply system is an important step towards strengthening capacity for efficient participation in agricultural biotechnology research. These facilities will not only lower the cost of research, which at present is very high due to the use of alternative sources, it will also remove the distraction of having to be involved in the provision of facilities by research organizations.

Providing more opportunities for human capacity building is also an important prerequisite to the 
acceleration of agricultural biotechnology research and development. The manpower available in research organizations must be motivated through the provision of training opportunities, especially in areas of advanced biotechnology. There is a dare need to develop research and other infrastructure to enable scientists venture into more advanced areas that are needed to solve farmers problems.

While this study focused on research organizations within the National Agricultural Research System. The activities of International Agricultural Research Centers (IARC's) in the area of agricultural biotechnology research could be a subject of further exploration. A clear understanding of the research and development capacities of the International Agricultural Research Centers within the country can provide significant input into building the capabilities of National Agricultural Research Centers.

\section{REFERENCES}

Adeoti, J.O. and T. Sinh, 2009. Technological constraints and vulnerability in selected developing countries (Nigeria and Vietnam). Proceeding of the 7th international Conference, Oct. 6-8, Dakar Senegal, pp: 1-29. http://globelics2009dakar.merit.unu.edu/papers/123 9029928_TB.pdf

Alabi, S.B., A.A. Babatunde and K.C. Egemba, 2007. Agricultural biotechnology. Medwell J., 2: 10191024.

http://www.medwelljournals.com/fulltext/rjas/2007 /1019-1024.pdf

Alhassan, W.S., 2003 . Agrobiotechnology Application in West and Central Africa (2002 Survey outcome). International Institute of Tropical Agriculture (IITA), Ibadan, Nigeria, ISBN: 9781311959, pp: 107.

FAO., 2004. The State of Food and Agriculture 20032004. FAO Agriculture SERIES, No. 35, Rome, Italy, $\quad 228$. http://www.fao.org/docrep/006/y5160e/y5160e17. htm
Horton, D., A. Alexaki, S. Bennett-Lartey, K.N Brice and D. Campilan et al., 2003. Evaluating Capacity Development: Experiences from Research and Development Organizations Around the World. ISNAR/IDRC/CTA, Canada, ISBN: 1-55250-1116, pp: 188.

Irefin, I.A., M.O. Ilori and B.O. Solomon, 2005. Agricultural biotechnology R\&D and innovations in Nigeria. Int. J. Agric. Resour. Ecol., 4: 64-80. http://ideas.repec.org/a/mes/ijarge/v4y2005ilp6480.html

Mathews-Njoku, E.C. and O.M. Adesope, 2008. Policy implication of the awareness and use of biotechnology products among farmers. http://www.ajol.info/index.php/jae/article/view/47057

Olaniyan, S.A., A.A. Bakare and O.A. Morenikeji, 2007. Genetically modified food in Nigeria: A long lasting solution to hunger? Estud. Biol., 29: 191-202. http://www2.pucpr.br/reol/index.php/BS?dd1=251 $0 \& d d 99=$ pdf

Ozor, N., 2008. Challenge and impact of agricultural biotechnology in developing societies. Afr. J. Biotechnol., $\quad 7$ : 322-330. http://www.academicjournals.org/AJB/PDF/pdf20 08/19Feb/Ozor.pdf

Sonnino, A., Z. Dhlamini, F.M. Santucd and P. Warren, 2009. Socio-Economic Impact of Transgenic Biotechnologies in Developing Countries: The Case of Plant Micro propagation in Africa. Electronic Publishing Policy and Support Branch Communication Division, FAO, Rome. ftp://ftp.fao.org/docrep/fao/011/i0340e/i0340e00.p df

The World Bank, 2005. Agriculture Investment Sourcebook. International Bank for Reconstruction and Development. The World Bank, $1818 \mathrm{H}$ Street NW, Washington DC., ISBN 13: 978-08213-6085-X, pp: 88. 